\title{
Germany's Brown Coal
}

\section{How Teuton Chemists Have Converted the Lowly Swamp Muck Into an Industrial Cinderella \\ By Robert G. Skerrett}

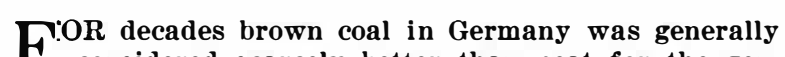
1 considered scarcely better than peat for the generation of heat. and was used sporadically by people who dug it for their own consumption because black coal was not available or cost too much for their modest purses. Broadly stated, brown coal may be termed bitum. ter which has not been subjected to the compression ter which has not been subjected to the compression and the high temperatures that brought about the formation of the well-known combustible. As brown coal comes from the ground it resembles woody, half-dried peat or muck such as may be found in many swampy forests it is dried the stuff may before and when dry the fibrous matter is apparently no more carbonized than the wood so often present in peat beds. The lignite, for such the fuel really is, is certainly unpromising when first dug, for its average mois ture content is about 60 per cent; and when most of this water has evaporated the material tends to crum ble. This affects both its keeping and its burning quali- doing in utilizing brown coal, and the data gathered is suggestively of great value. From the facts garnered by our experts it is not hard to realize why the Teutons are undismased by their enforced separation from the bituminous coal fields which were formerly under their cituming contical thickness ranging from tical thickness ranging from 32 to 328 feet with an average of 72 feet. The deposits are overlaid by relatively thin strata of gravel and clay, and this overburden is removed to facilitate the mining of the coal by open-cut methods. The gravel and clay are cleared away by steam shovels which dump the stuff directly on to cars that carry the spoils to banking grounds. Not infrequently, clas-working plants are operated close by and employ the brown coal for fuel.

When a satisfactory area of the brown coal has been exposed, movable rails are laid and powerful excavating machines of the chain-and-bucket pattern are advanced on them to the desired points of action. There
the face of the cut is attacked at an angle of from 45 close to the pit, and is typical of kindred factories reared at numerous points throughout the lignite fields of Germany. The establishment is supplied daily with 800 carloads of the raw material, each load weighing 1,320 pounds.

The lignite is passed through one or two pairs of crushing rolls and is screened by inclined vibrating sieves, and such of the stuff as still remains coarse is carried through a third crusher. The woody parts and hard lumps which will not drop through any of the sieves are taken by a belt conveyor to the boiler furnaces and there burned. In the course of ten or twelve hours enough brown coal is crushed and screened to supply the briqueting machines for a period of twentyfour hours. One man can look after the functioning of two sets of sieves.

The duly crushed, fine, moist lignite is distributed by belt conveyors to bins near the driers. The driers are sheet-iron cylinders 23 feet long and 10 feet in diameter, supported on trunnions and mounted longitudi-

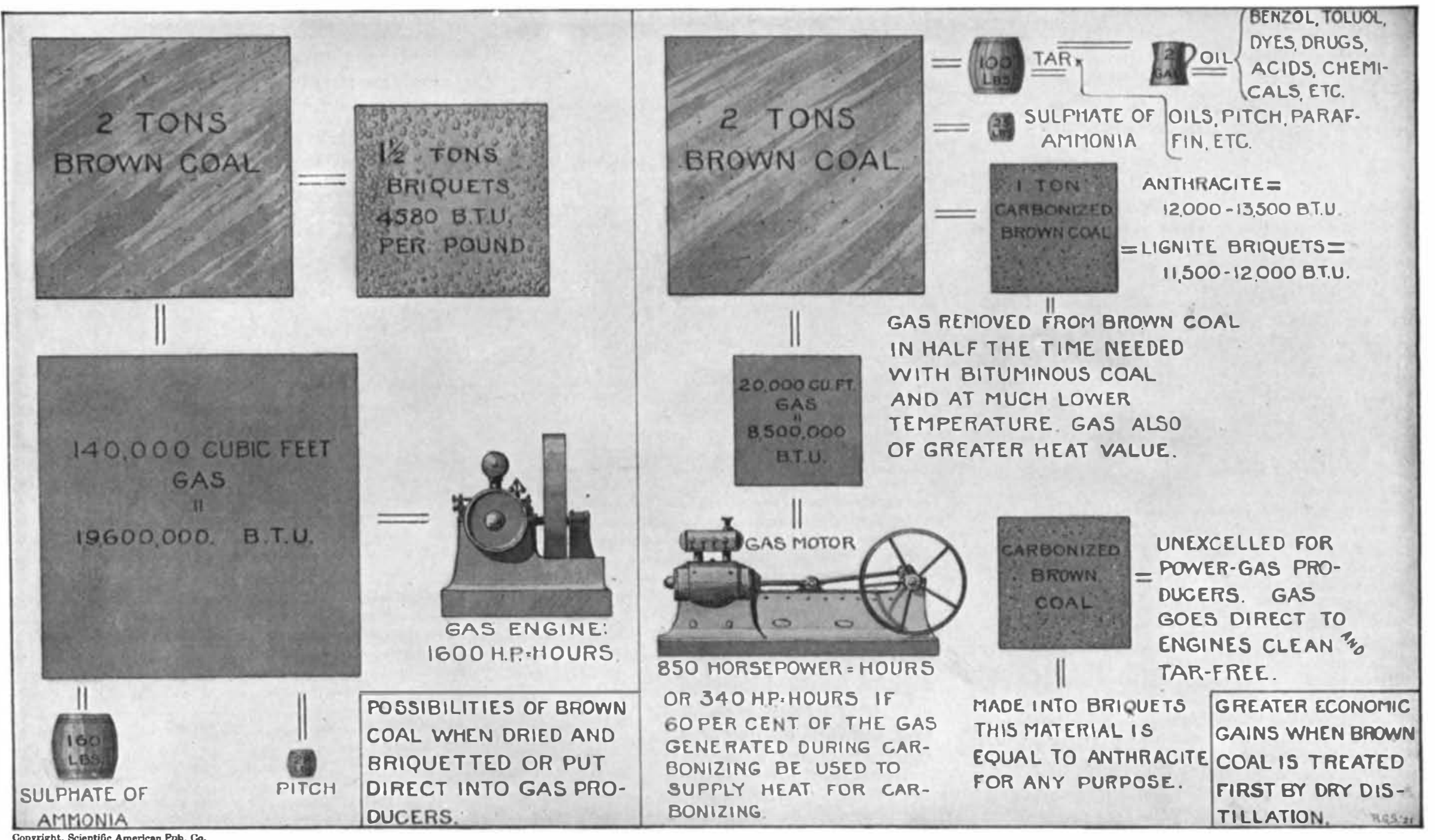

Diagrammatic showing of the benefits that Germany can reap by the skillful use of her inexhaustible beds of brown coal

ties, more especially if the ordinary grates are used. offhand, one might be justified in the assumption that no nation, until hard put to it, would take any that no nation, until hard put to it, would take any
serious steps toward exploiting a fuel that seems to serious steps toward exploiting a fuel that seems to
have so little to commend it. Yet, back in the "nineties," the Germans saw possibilities in their widespread and well-nigh inexhaustible deposits of brown coal, and with typical Teuton thoroughness evolved, in a comparatively short while, ways and facilities by which the initially indifferent combustible could be which the inito a fuel of undeniable merit. They did this by a briqueting process; and from a friable, unsta ble commodity they made a product that would stand rough handling and endure exposure to the weather for months without disintegrating. Right here let it be emphasized that Germany's brown coal is much inferior in fuel value to most of the lignites that pre vail abundantly in certain sections of the United States.

The U. S. Bureau of Mines has kept in touch as far as practicable with what the Germans have been to 50 degrees, and each machine disposes of a slice of lignite to a depth of 43 to 49 feet. The succession of sharp-edged buckets, trailed by an endless chain, dig into the exposed slopes of the beds as they are dragged from the bottom to the top of the excavation. The buckets empty into hoppers from which the brown coal is loaded into small cars having a capacity of 1.3 cubic yards. One mechanical excavator, calling for the attendance of only three men, can cut about 1,650 tons in the course of 24 hours. The flled cars are drawn in the course of 24 hours. The filed cars are drawn by locomotives to a station where they are attached to
a chain belt which pulls them up an incline to the a chain belt which pulls them up an incline to the
upper floor of the briquet factory. When the excavaupper floor of the briquet factory. When the excava-
tions reach still deeper, the chain-tractor system is extended to the terraces adjacent to the steam diggers, and the laden trams are then hauled right from the pits without the aid of locomotives.

One of the best examples of a brown-coal briqueting plant is that at Zisselsmarr, in the neighborhood of Cologne. It is a substantial brick structure placed nally at an angle of 7 degrees from the horizontal. Lach drier contains an inner cylinder carrying more than 360 four-inch tubes set parallel with the axis of that drum. Exhaust steam from the plant engines circulates around the tubes through which the damp coal is moved continually under the impulse of spiral feeders. The speed at which the ground material travels through the drier depends upon its moisture content. When this is 60 per cent the passage takes about 45 minutes; and during that time the mos is reduced to 15 per cent. There are several driers, and each has a capacity of 77 short tons of dry lignite every twenty-four hours. It is said that the air in all parts of the establishment is substantially free from fioating dust by reason of certain precautionary features, and this effectually obviates any risk of dust explosion-a danger that was not absent from some of the earlier briqueting factories. Before the war the drying cost was $17 \%$ cents per ton of product. (Continued on page 315 ) 


\section{A New Form of Hydraulic Propulsion}

(Continued from page 301)

through $A$ divides and passes into the impeller through the unmasked portions of the holes in the sides of the drum. This internal drum can be rotated about the impeller shaft by means of the lever shown and can be held in any desired position. When it is set as shown in the
drawing, the orifice for the discharge drawing, the orifice for the discharge stream is of maximum area and the drum be rotated clockwise, the effective area of the discharge port and also of the inlet ports is reduced. As a consequence, the rolume of water handled by the impeller and the speed of the vessel is lessened. In the extreme position, as shown in dotted lines, the inlet ports and the outlet port are completely masked, the impeller merely churns the water inside the casing, and the engine is practically relieved of the load. Consequently, no the engine and the pump.

Now, let us suppose that the inner drum is rotated anti-clockwise from the position shown in the sille view. The effect is first to decrease the outlet orifice and throttle the discharge streala. The continuation of the rotation results in the passageway 1 being increasingly opened by the orifice in the periphery of the drum, while the unmasked portions of
the side orifice remain substantially conthe side orifice remain substantially con-
stant in area. In this condition a portion stant in area. In this condition a portion
of the discharge stream is sent rearward and a portion forward through the passageway $t$. If the morement be continued a point will be reached at which the momenta of the two portions are equal and the vessel will remain stationary, although the engine is running under ful load. Still further rotation will result in the entire clischarge stream being delivered forwardly to $A$. when the propulsive equipment will

Since the two pumps are controlled independently, one may be set full ahead and the other full astern, and the boat can be turned within its own length; in fact the course of the vessel can be controlled
by the pump only, if so desired. In its inrestigation of this very interesting experimental boat, The Engineer found that the speed developed at 950 revolutions and $7 \% / 4$ brake horsepower was $\mathbf{0 . 6}$ knots, and the calculations by Mr. Hotchkiss, the inventor, showed a jet efficiency of 73 per cent. He assumes the efficiency of the
pumps at 90 per cent, and thus arrives at a propulsive efficiency of 65.7 per cent. Taking the engine efficiency at 75 per cent, the over-all efficiency works out at 49.3 per cent. This, The Engineer considers would be a fair showing in a vessel prothough our contemporary takes no responsibility for the data on which the calculation is based.

It should be mentioned that the pumps can be arranged to draw their supply of water from within the hull, in the event of the vessel being holed; and if the pumps are capable of handling in twelve seconds or so, as is claimed, a weight of
water equal to the displacement of the vessel, they should be able to salvage a craft in which they were fitted, eve

\section{Germany's Brown Coal}

\section{(Continued from page 30\})}

From the driers the coal goes through pulverizers which reduce it to fairly uniform size; thence the powdered material is shifted mechanically to a cooling room fitted with slanting floors or shelves over which it drops by gravitation; and at the is in a condition to be handled by the briqueting presses to which it is led directly. The presses are of the open-mold plunger type, which subject the pow-
dered brown coal, containing about 15

\section{NEW BOOKS, ETC.} Personnel Administration. Its Princi-
ples and Practice. By Ordway Tead ples and Practice. By Ordway Tead
and Henry C. Metcalf, Ph.D. New York: MeGraw-Hill Book Company, $1920.8 \mathrm{vo} ; 538 \mathrm{pp}$.
The fallacious but still dominant formula hat results are directly proportional to the power of enforcing obedience, fails to cover
the complex relationship between managers the complex relationship between managers
and managed. We glimpse the fact that the and managed. Ne glimpse the fact that the
quality of the obedience as determined by the quality of the obedience as determined by the
mental reactions of the managed is overwhelmingly important-economically as well as sociologically, if indeed the two factors are
ever sunderabe. In "Personnel Administra ever sunderabe. In "Personnel Administra-
tion", we find a sane balnncing of these constituents, a comprehensive surrey of the field, an
evaluation of extucational and health ele evaluation of eltucational and health ele-
ments, specitic research, the coirdination of departments, and joint relations. Vital topics are logically grouperd and suggestively handled
for the benefit of students, executives and emporers. The best practice erom innumerable
plose ployers. The best practice from innu.
sources is incorporated in the volumie.

Direct-CukReNT Motor AND Generator Trotrir. ES. By. Theodore S. Gandy and
Elmer C. Schilcht, I.t. J. G., U.S.N.R.F Elmer C. Schitchit, I.t. J. G., U.S.N.R.F
New York: II Graw-Hill Pook Com pany, 1920. 8ro.; 274 pp.; illustrated.
This is in the main a compilation of the simplest and most effertive methods of tracing and correcting troubles, preceded by ade-
quate descriptions of the various types of quate descriptions of the varions topes
motors and generators, and their uses. There is aiso an analysis, fromt he operator s stand
point, of problems centering alout operation care, and repair. The ilustrations are necesinstruction is so given as to be general, and
ind applicable to the operation of all types. The question, "What is the matter " confronts
the operator again and again ; in giving a true, understandable answer, this handbook fills a daily need.

AMERICAN MachinISTS' HANiBbook AND Dictionary of SHOP 'TERMS. By Fred
H. Colvin and Frank A. Stanley. New York: MIcGraw-Hill Book Compar
1920. 16mo.; 758 pp.; illustrated.

1920. 16mo.; 758 pp.; illustrated.
Shlop and draughting-room are not immune from change, and this third edition of a work
that is creating many friends for itself takes that is creating many friends for itself takes
the changes into due consideration and adds much timely information. Mathematics being
the heart of mechanics, the tables and data here carefully selected and brought together,
some of them from almost inaccessible sources, some of them from almost inaccessible sources,
will soon pay for the elbow-room they occupy; tools, processes and accepted practice are
treated at length; shop and drawing ronm standards, horse-power, belts and shafting. and shop trigonometry are presented in con
venient .arrangement, and the illustrated dic enient arrangement, and the ellustr.
tioary of terms is a valuable feature.

Mechanical Diraniling ror High Schools. A Text with Problem Layouts. By
'Thomas E. French and Carl L. Svensen. New York: IIeGraw-Hill Book Company, 1919. 8vo.; 221 pp.; illustrated.
In many ways this is an exceptionally good In many ways this is an exceptionally good
text, and will be recognized as such by the industrial educator. More than the ordinaly using the drawing board and instruments: shape visualization and description are rightly shape visualization and description are rightly
treated as of prime importance; other expo. sitions include the technic of the finished
drawing, mechanical and architectural practice, and graphic solutions and sheet-metal drafting. Eighty pages of problems cover al
phases of the study, and the instructions are mply illustrated.

Human a NJ Industialal Efficiency. By
Henry Chellew, I'h.D., D.Sc. P'reface Henry Chellew, I'h.D, D.Sc. Preface
by Rt. Hon. Lord Sydenham, F.R.S. New York and London: G. I'. I'utnam's
Sons, 1920. 12mo.; 149 pp. Sons, $1920.12 \mathrm{mo} ; 149 \mathrm{pp}$.
This short stumly of the actors of efficiency
recognizes two fatigues, "'and the most imporrecognizes two fatigues, "and the most impor
tant is that of the mind." Lord Sydenham, in his preface, lays unrest at the door of our neglect of the psychological requirements of
the human machine, and the author, whose the human machine, and the author, whose
instruction at the Lniversity of London will instruction at the lniversity of London will
be remembered hy many American officers, writes as practical philosopher rather than as
engineer. His synthetic study gives brief engineer. His synthetic study gives brief
glimpses of the broad field, and is but the forernner of a projected volume that will deal
more exhaustively with vocational adaptation more exhaustion
and training.

Motor QUERY Fincyclopedia. Cincinnati: American Automobile Digest, 1919
16mo.; 129 pp.; 160 illustrations.

A very large proportion of our people are
practically interested in motors. Questions as
of civilization in North America, with stric their minds. The chances are that you will find your pressing question of the moment swered to your full satisfaction. Axles, batteries, chassis, clutches, cooling, lighting, ignirery, steering gear, transmission-in short,
everthing about the car is explained in brief, imply-worded paragraphs.

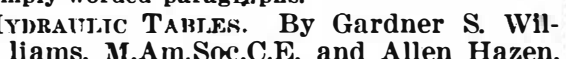
liams, M.Am.Soc.C.E. and Allen Hazen,
M.Am.Soc.C.E. New York: John Wiley M.Am.Soc.C.E. New York; John Wiley
and Sons, 1920. 8vo.; 115 pp.; illustrated.

These important tables, accompanied by tion of water flowing in pipes, sewers, etc., as determined by the Williams-Hazen formula, and the flow of water over sharp-edged and ir-
regular weirs and the quantity discharged. There is a new chapter of additional data in
Thers and the quantity discharged his third edition, and a graph showing the relations of the chief results both new and old.
These tables have proved their value in fifteen ars of use.

Exico is Irevolution. By V. Blasco
Ibañez. Translated by Arthur LivingIbañez. Translated by Arthur Living-
ston and José Padin. New York: E. P. ston and José Padin. New York: E. P.
Dutton anłl Company, 1920. 8vo.; 245 pages.

Ibañez. caught in the "vertiginous" storm of about. These a a rticles first appeared in Ameriacter, and politics parade before the edified reader. Bonillas, Otregon and (ionzalez are
Irawn with a sure hand, the condition of the United States, amusing and serious elements mix to define a situation
all have more knowledge.

Mascat of the Timasers of the World. By Alexindler L. Howard. New York:
The llacmilliul Company, 1920. 8vo.; The Nac(mill:ul Company,
446 pp.: 106) illustrations.

This notable handbook is intended to supplement rather than to supersede other works.
The characteristics and uses of all commercial timbers are alphahetically catalogued, picthe conversion and preservation of timber, specifications and conditions of contract, Las

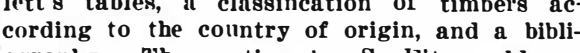
ography. The section hy $\mathrm{S}$. Fitzgerald, on
artificial seasoning, is a noteworthy feature, artificial seasoning, is a noteworthy feature,
and there is an index to scientific names in addition to the general index

Surface Water Supply of The United STATES. 1917. Part I. North Atlantic
Slope Drainage Basins. Washington: Government P'rinting Office, 1920. 8vo. 200 pp.; : plates.

garey durments of flow made on streams, occupy 14

ryports, of which this is one. It describes the
ypical gaging station and its equipment, and Slope.

Axmrican Lubricants. From the Standpoint of the Consumer. By I.. B. Lock-
hart. Laston, Pa.: The Chemical Pubhart. Kaston, Pa.: The Chemical Pub-
lishing Company, 1920. 8vo.; 341 pp.; illustrated.

The diference between this and most other
ooks on lubrication is iudicnted in the subtle; the user's interests are made paramount and the buyer and consumer of oils and reases is taught to select intelligently thos
best suited to his purposes. From crinde pe troleum to its refined products, characteristics and properties are described; solid and
fluid friction and the lubricants and systems his come chanters on the demands of special
machinery, from the internal combustion entgine to the steam railway. Mills and plant ses, and up-to-date specifications are dealt The Coionization of North America. 1492-1783. By Herhert Eugene Bolton,
Ph.D. and Thomas Maitland Marshall, Ph.D. and Thomas Maitland Marshall,
Ph.D. New York: The Macmillan Company, 1920 . 8vo.; 609 pp.; 49 maps. Eastern insularity may be to blame; how
ver that may be, it is a fact that most of our works on colonization are devoted to the thir-
teen English colonies, slighting France, disteen English colonies, slighting France, dis
missing Spain with a word, and largely ig. oring Holland, Sweden, Russia and Denmark. The substantial volume in hand corrects thi narrow viewpoint and brings local develop
ments together as integral parts of a com. plete picture. It rehearses the whole dram
of civilization in North America, with strict attention to time sequence and the comparacan newspaners, and they constitute a chatty, countrs is set nakedly before us, and in the ealing with them are discussed; following with at great length. Important tables con-

tive importance of racial activities. This
breadth of treatment is commendable. and breadth of treatment is commendable. and
readers will gain from it an expanded consciousness of the multiplex factors that left tionary war.

Fuel OIL IN Industry. By Stephen 0. Andros, A.B., E.Mr. Chicago: The
Shaw Publishing Company, 1920. 8vo.; $244 \mathrm{pp}$.; illustrated.

The principles of fuel oil combustion and its physical and chemical properties are here
outlined in a highly satisfactory manner. There is a comparison of coal and oil fuel, a chapter on colloidal fuel, and a long and
valuable discourse on distribution and storvaluable discourse on distribution and stor-
age. Other chapters treat of heating and numping; boiler furnaces; fuel oil burners fuel oil in steam navigation, locomotives, iron
and steel manufacture, the production of electricity; in the sugar, glass, and ceramic in making of gas. The publication is timely, the heme well handled, and the appeal wide.

Covrse in Practical Mathematics.
By F. M. Saxelby, M.Sc., B.A. New York and London: Longmans, Green and Company, 1917. 8vo.; 472 pp.; il lustrated.

This thorough course takes cognizance of
he needs of the technical student. The deductive treatment is accompanied at ever tep bs graphic or arithmetical verification hy the facts of experience. 'Thus the mind is radually prepared for the analytical method differentiation, and trigonometry is made comprehensible to the earnest student. The
same method is extended to the mastery of definite integration, and the best educational order of subjects is followed, rather
merely logical or historical order.

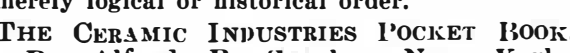
By Alfred B. Searle. New York
Isaac Yitman and Sons, 1920. 16mo. 267 pp.; illustrated.

From various sources this manual takes information that has been of practical assistance
to those engased in the clay-working, glass. to those engaged in the clay-working, glass,
and allied industries, and arranges it in convenient form. It describes materials, gives ata on water and steam, briefly treats of merelating to machinery and burning and kilns, nul presents ceramic calculations. A bibliography and a list of technical and other associa. tions round out a handbook of high value to tudents and workers.

Dictionary of Explosives. By Arthur Marshall. Philadelphia: P. Blakis- 


\title{
Recently Patented Inventions
}

\author{
Brief Descriptions of Recently Patented Mechanical and Electrical Devices, Tools, Farm Implements, Etc.
}

Pertaining to Apparel

106 w. 79th St., New York, N. Y. This invention has for its object to provide a construc tion which may be easily attached to the gar ment and which in operation will properly hold ment or disengagement. A further object is to provide a fastener in which a bridge and interlocking tongue are used, and giving the finished appearance of a rounded button.

Shoe fastexer.-B. A. Shammo, $106 \mathrm{w}$ 79th St., New York, N. Y. This invention re lates to a fastening device which is espe-
cially adapted for use with shoes. An object is to provide a fastener wherein a proper clasping action is secured when first used, and means are presented which will permit a
readjustment of the parts to maintain a desired position of the garment fastened, and which will thereby automatically take up any stretching or distending of the material of the article

\section{Electrical Devices}

SWITCH FOR FLASH LIGHTS. - H. M. KoRE'TRK, c/o Bright Star Battery Co., 310 larly the invention relates to a switch for intermittently or continuously closing the cir suit of the battery and lamp. The general
object is to provide a combination of pushbutton and slide button so arranged that they are employed independently for closing the circuit by engagement with the contact strip circuit by engagement with the co
within the casing of the flash light.

StORAGE BatTerY.-P. M. Marko, 1191 Bedford Ave., Brooklyn, N. Y. The invention has for its general object to provide a form of
jar cover which permits of the level of the jar cover which permits of the level of the
electrolyte to be easily and quickly ascertained without removing the vent or filling plug; this
is accomplished by the making of the cover of is accomplished by the making of the cover of
transparent pressed glass of special design, transparent pressed glass of special design,
a nd within the cell are two distinctly colored and within the cell are two distinctly colored
arrows attached to the terminal posts, which arrows attached to the terminal posts, whic
serve as means for determining the proper level of the electrolyte.

ELECTRIC SWITCH.-A. M. Condit, 19 Essex St., East Orange, N. J. The object of
the invention is to provide an electric switch the invention is to provide an electric switch arranged to permit of conveniently closing an
electric circuit temporarily or for any length electric circuit temporarily or for any length of time according to the desires of the user,
and without requiring his attention for the and without requiring his attention for the
time being. Another object is to permit of
conventisty attaching the switch to a desired conveniently attaching the switch to a desired support on an automobile for use in signaling derices to enable
display signals.

BLASTING APPaRatuS.-S. T. Hoar, 2216 Cottonwood St., Ifeaderville, Mont. The invention relates to electrical apparatus for use in blasting, and has particular reference to a cuits for exploding closing a number of cirther object is to provide an explosive charge which may be completely assembled before being distributed to the miner, so that all the hole to be blasted and connect it in the circuit. ELECTRIC LIGHT FINTURE.-B. B. STEN valL, 521 45th St., Brooklyn, N. Y. The in ventinn has for its object to provide a fixture
of the type generally employed on a desk, the important features residing in means for variously adjusting the light, novel supporting means and the manner of arranging the conductor cord with respect to the adjustable and
supporting elements, whereby the light may be employed as an effective and convenient be employed
searchlight.

\section{Of General Interest}

GARMENT HANGER.-II. ROSENTHAL, 501 W. 170th St., New York, N. Y. Among the ment hanger which in addition to supporting a coat, or similar article, is capable of supporting a plurality of other garments, and also
has the advantage of having the supports for the other garments removably attached. The device mas be formed of wood or metal, an
either rigid, or foldable for convenience of travelers.

STONE MOUNTING.-A. L. ELIASOFf, an The invention relates to jewelry, and more particularly to ornamental gem settings. A light reflecting medium which adds to the charm and luster, and also provides means for
securely anchoring a precious stone in the prongs of a ring, the prongs being protected from wear, thus decreasing the possibility of the loss of the stone.

TRAFFiC REgister.-G. Henry, 55 Artigny St., Quebec, Canada. It is the pu pose of this invention to provide a sytematic automatic and continuous registration of the object being to provide an apparatus which will

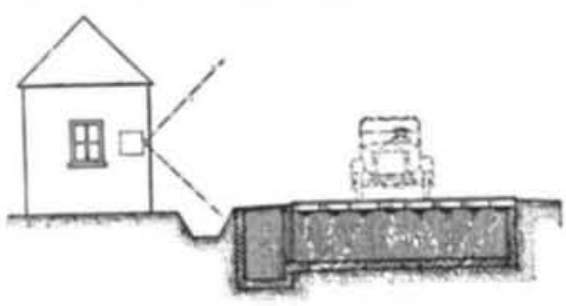

A VIEW in Section, Showing a Vehicle PASSING THE POINT OF OPERATOR

take an instantaneous photograph of traffic on street or road, so that vehicles of all speeds in such form that the film may later be used as a permanent record in connection with a projecting device.

ARTIFICIAL LIMB.-J. W. SMith, 1621 Francisco Ave., Chicago, 111 . It is one of the
objects of this invention to provide an artiobjects of this invention to provide an arti-
ficial arm which is capable of use in cases where the natural arm has been amputated either between the shoulder and elbow or he-
tween the elbow and the wrist. A further object is to construct an artificial arm in such manner that the forearm section is movable with relation to the upper arm section, the hand section universally movable with respect
to the forearm, and the finger sections movable to the forearm, and the finger sections movable with respect to the body portion of the hand,
the finger sections having means to cause them the finger sections having means

MOVING PICTURE CAMERA AND PROJECTOR.-D. Taifinnopovlos, 67 Cherry St New York, $\mathbf{N}$. Y. An object of the invention is quickly and easily adjusted or rearranged to act as a camera or as a projecting machine. A further object is to provide a simplified and small construction for family use, the structure
being such that a minimum of space will be require for its use.

SNAP ORNAMENT FASTENER.-N. BAN New York, N. Y. The invention relates to
New, Triedman, 233 Broadway, an ornamental stud or button. An object is to provide a snap fastener which is adapted for use as an ornament or as a fastening means
for a garment, and which permits the removal of the stud during the laundering operation of the garment so that the ornamental exterior the garment so that the ornamental exterior
of the fastener will not be broken or injured. CONCENTRATING TABLE.-J. F. McNeil, Death Valley, Cal. In order to obtain a larger proportion of concentrates and increase the
capacity of the table with minimum power, this patentee arranges a series of oblique riffles inclining upwardly toward the high side of the table and adjacent to the opposite side, or axis of the table. Between the two series

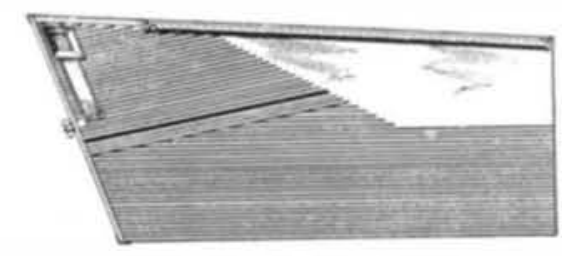

PLAN VIEW OF THE TABI,

rifl'es is a bank riffle the top surface of which slowes toward the tailing side, all the riffes being gradually of reduced height toward the discharge end of the table. A feed device exessentially a feeding to all the riffles adjacent the head of the table. The bank riffe re
sults in a pond being formed at the area of the oblique riffles. The material is required to travel upward toward the high side of the table before escaping to the table surface to
carried laterally toward the parallel riffles. DEVICE FOR USE IN LEARNING TO SWIM.-G. Jordahn, Palm Beach, Fla. invention relates more particularly to an in a table device adapted to encircle the body and clude accidental in such manner as to preprovided with means for readily tying the ends of the tube, which tying serves the double function of retaining air in the tube and
properly holding the tube around the body. CLOTHESLINE CLAMP.-W. A. JohnSON, 202 Quincy St., Fairmont, W. Va. Among the objects of this invention is to provide a simple, inexpensive and efficient metal hook and
eye clamp which will effect a locking of the eye clamp which will effect a locking of the
clothes line to the prop so that accidental displacement of the line is positively prevented the only way in which the line can be removed from the clamp is by manually removing the ese from the hook.

CONTAINER FOR CEDAR SHAVINGS.J. E. Tracy, Box 839, Orlando, Fla. The in vention relates to a comparatively small box which may be placed in a trunk or clothes
closet for preventing moths from attacking closet for preventing moths from attacking
the clothes. The purpose is to provide a container which will allow of the exposing of
cedar shavings to the air at the same time cedar shavings to the air at the same time
preventing the shavings from being displaced. STORE SIGN.-B. H. SCHAKF, 635 W. 170th St., New York, N. Y. An object of the invention is to provide a sign with a changeable displas to be mounted on the door and readable through the glass of a store door or other institution having public patronage announce whether or not the store is open and a spirit of welcomeness to customers entering and leaving.

HUMidifieR.-L. A. Sмith, Port Gibson, Tississippi. This invention has for its object to provide a small portable humidifier capable means of which a cigar may be simultaneously hy drawing a blast of air laden with the flavoring through the eigar.

\section{Hardware and Tools}

RAZOR.-D. A. Fenwick, Box 222, Bisbee, Arizona. The invention relates more partic ularly to a razor having a removable double
edged blade supported in a holder or frame which has the general appearance of and operates in the same way as the ordinary old styl razor. An object is to provide means for se-
curing the razor in the holder and permitting the use of a thin steel double edged blade which can be sharpened on
and cheaply manufactured.

CURTAIN ADJUSTER.-E. M. MEnzL, cor. Riker and Stein way A ve., Steinway, Long Island City, N. Y. Among the objects of the invention is to proride a neat and inconspicuous cross bar, which when in operation will hold a sashes so as to afford a free flow of ventilation, and prevent the blowing of the curtain or the soiling thereof, and permit unobstructed
cleaning of the window and other purposes. COMBINATION SCALE JACK STEELE, 59 W. 44th St., New York, N. Y. The invention relates to a device such for exam ple as lifting jacks and weighing or load indicating devices. Among the objects is to pro-
vide a relatively simple implement easily mavide a relatively simple implement easily ma-
nipulated by any ordinary person for the pur pose of checking the weight of loads such a coal, grain or hay, when carried ei
horse-drawn or self-propelled vehicles.

We wish to call attention to the fact that we are in a position to render competent services in every branch of patent or trade-mar
work. Our staff is composed of work. Our staff is composed of mechanical,
electrical and chemical experts, thoroughly trained to prepare and prosecute all patent applications, irrespective of the complex nature
of the subject-matter involved, or of the of the subject-matter involved, or of the
specialized, technical or scientific knowledge required therefor.

We also have associates throughout the world, who assist in the prosecution of patent and trade-mark applications filed in
tries foreign to the United States.

MUNN \& CO., Solicitors of Patents

Woolworth Building,

Tower Building,

NEW YORK Scientific American Bldg., WASHINGTON, D. C. SAN FRANCISCO, CAT,

per cent of moisture, to a pressure of from 18,000 to 22,500 pounds per square inch. The briquets are lozenge-shaped, 7 inches long, and $21 / 2$ inches wide, weighing 1 pound each. No binder is required because the heat of compression liberates cause the heat of compression liberates
from the lignite sufficient tarry matter to insure adhesion. Each press has a capacity of 77 short tons of briquets during 24-hour run; and 120 horsepower are required for its operation.

Because the briquets are very hot when first molded, it is necessary to cool them to guard against ignition if they be piled immediately. Therefore, they drop from each press into a trough-shaped conveyor which moves the briquets to the storage sheds; and this journey of 325 feet is long enough to chill them sufficiently.

Shortly before the war a large central power station for the generation of elecricity was placed at a brown-coal mine in the Cologne district, and was able to urnish current to that city at the rate f about $3 / 4$ cent per kilowatt hour. Two years ago Mr. George S. Rice of the Bureau of Mines was in that neighborhood, and at the Fortuna mine he visited a cen-
tral station which was developing 40,000 tral station which was developing 40,000 electrical horsepower and transmitting that energy to Cologne 12 miles away. Such of the brown coal as was not burned under the boilers was being made into briquets, which were used in competition with bituminous coal both on the railways and for factory and domestic use. It has been proved by the Germans that boilers can be constructed that will work well when fired with either hard-coal or hrown-coal briquets. It seems that the tially the same for continuous operation. Brown-coal briquets, however, are less Brown-coal briquets, however, are less
suitable for intermittent service. A wellknown German engineering concern has recently developed a special boiler for the use of brown-coal briquets and even inferior grades of fuel, and the tests have been highly satisfactory. The efficiency is per cent.

How great this industry is can be readily grasped from the following comparaive figures: In 1913 the brown coal output totaled $79,741,825$ tons, and last year it aggregated 121,202,215 tons. Relatively 5 per cent less of the lignite production was worked into briquets during 1920 and this probably indicates not only 


\section{DURAND STEEL RACKS}

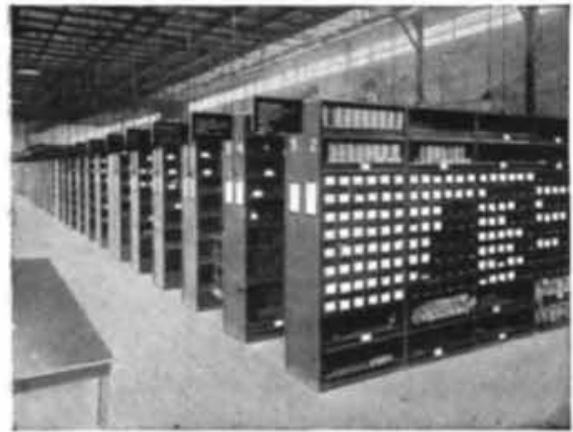

$\mathrm{D}^{\mathrm{U}}$

URAND Steel Racks make possible any arrangement or grouping of stocks desired, regardless of the kind of goods stored.

Goods may be stocked alphabetically or according to grades or sizes, or by classifications, or by component parts, or according to catalog listing.

By means of cards in holders on bin and shelf fronts and sides a perpetual inventory may be kept with little effort.

Write our Engineering Department if you have stockroom problems.

DuRand Steel Locker Co. 1574 Ft. Dearborn Bank Bldg. 574 Park Row Bldg. Chicago New York

Experimental and Model Work Ine Instruments and Fine M

Special Tuols, Dies, cear Cuttling, Etc.
HENRY ZUHR, 489-93 Broome St., New York City

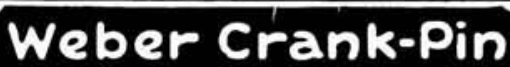
Re-Turning Tool

No Filing

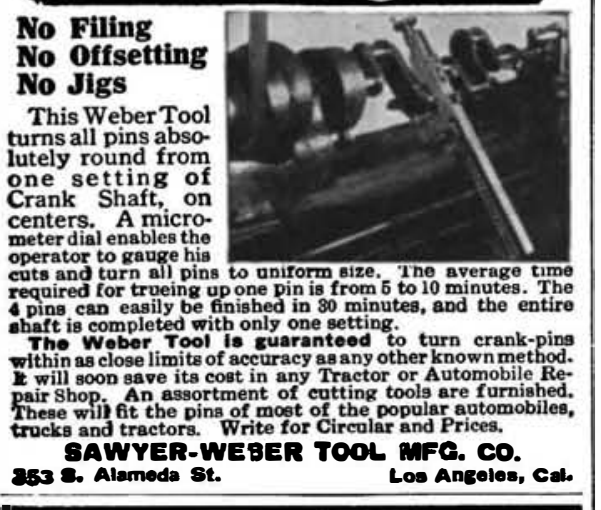

W DLLILLING $_{\text {EL }}$

A Paying Business

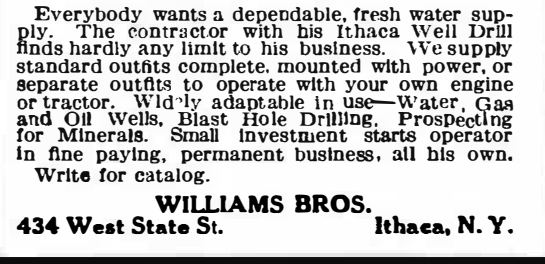

selves with facilities for this purpose. To this end, the authorities have put a premium upon the distillation of lignites by promising to remit the coal tax case of the brown coal so treated.

About a year back a German technicist stated, in making an address before the Prussian Ministry of Public Works, that one ton of brown coal would yield enough gas to generate 408 kilowatt hours of electricity, and provide in addition 77 pounds of tar, 8.8 pounds of pitch, 8.8 pounds of paraftin, 8.8 pounds of "solid oil," and 22 pounds each of two other kinds of induspoul at that time the expert said that a method had been discovered by which edible fats, suitable for the manufacture of margarine, could be derived from this coal tar, and it seems that soap has been made from the same source. Another consequence of the peace treaty is Germany's obligation to give to France each twelvemonth also for three years 30 , 000 tons of ammonia and here, again, brown this discover of industrial salvation is this discovery of industrial salvation is heralded as another proof of Teuton technical cunning, it serves the while to confirm independent work done on this side of the Atlantic by some of our own people even before the World War. It was found here that from the distillation of ignite it would be practicable to realize approximately 17.4 pounds of ammonium sulphate per ton of the dried fuel, and the Germans are turning this fact to good account in the treatment that they have adopted.

It is now well known that lignite, if carbonized at the relatively low temperature of about 1,200 degrees Fahrenheit, will rive off gas freely and that the byproducts recorered will be of satisfactory grolity. Above that temperature the de作 structive distillation of the tar in the raw fuel begins, and the greater heat not only reduces the amount of recoverable tar but affects the character of that material and the oils that may be subsequently obtained from it. It has been established that heary oils from lignite tar are admirably suited for use in internal combustion ensines because the oil does not deposit tarry matter. And what is of equal significance, lignite gas is what is termed a "dry" gas-i.e., it is substantially free from tar, and gives no troublesome condensation when distributed through slightly protected pipes even in cold weather. The gas is well adapted to power purposes.

Probably one of the most interesting phases of the of the most interesting coal or lignite is that the carbonized residue, of very little value in the form in which it comes from the retort, may nevertheless, be converted into a really excellent smokeless fuel by briqueting. Indeed, briquets of this nature are distinctly superior to those made from dried brown coal Comparative tests with high-grade bituminous coal have shown carbonized lignite briquets to be more efficient. For instance, 3.76 pounds of briquets and 3.88 pounds of soft coal were sererally required to develop a horsepower hour; the quantity of water evaporated per pound of fuel was, in the case of the briquets, 9.18 against 8.88 pounds on the part of the bituminous coal; and the average boiler horsepower developed was 98 with the soft coal and 101.5 with the briquets. It should be kept in mind that, by exhaustive distillation and treatment of the tars and oils, it is practicable to derive hundreds of synthetic products, such as paraffin, acids, antiseptics, photographic chemicals, aniline dyes, drugs, perfumes, preservatives, etc. From the light oils can be got benzol, toluol, dyes, photochemicals, certain drugs, etc From the carbolic and creosote fractions are obcarbolic and creosote fractions are obtained carbolic acid, creosote, picric acid, photodyes, coloring materials, perfumes, etc. The anthracene oils yield, among used in the production of dyes, and carbolineum, effective as a wood preservative.

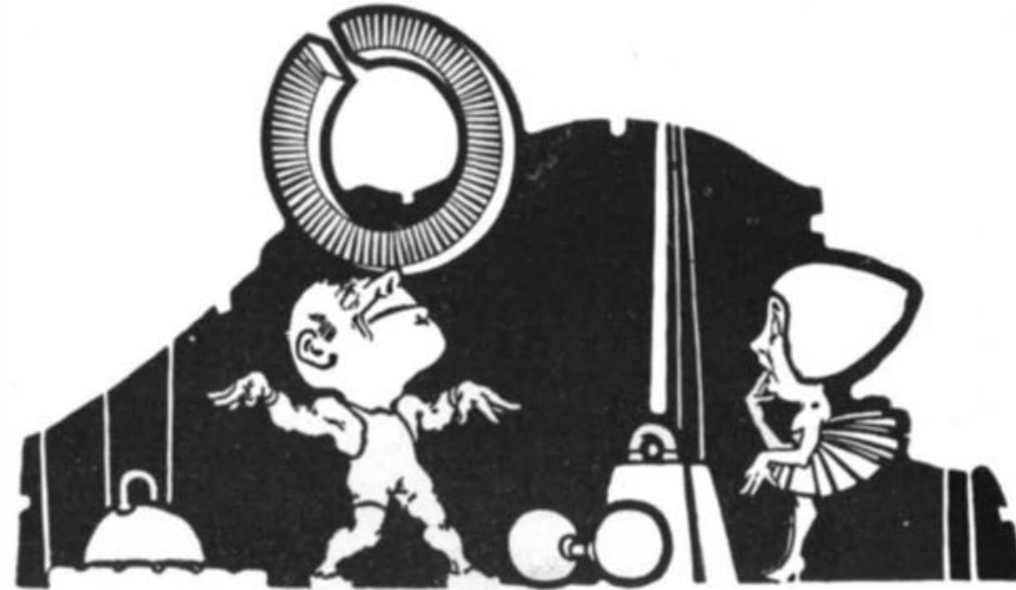

\section{for the price of a good show}

You can buy our user's assortment of Neverslip Lock Washers-enough to keep the average automobile free from rattles for many years!

The Engineering Department of the Curtiss Aeroplane Co. devised a special apparatus for testing the gripping power of lock washers. In engines subject to the tremendous vibration of the aeroplane motor, you can understand how important it is that every nut should deliver its maximum gripping efficiency. So Neverslip Lock Washers were tested in comparison to the ordinary lock washers and were proved to have $60 \%$ greater gripping power.

A copy of the report made by Curtiss engineers, showing the apparatus used and the various tests undertaken, will be mailed you on request. The

NEVER SLIP

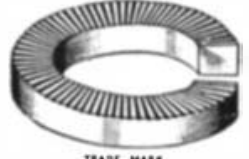

\section{LOCK WASHER}

is easily identified by its corrugated gripping surfaces. These corrugations are exclusive to Neverslip and are responsible for its greater gripping efficiencv

It is not only important that you use lock washers but - since the cost is the same-it is important that you use lock washers on whose quality and gripping efficiency you can always depend.

Neverslip Lock Washers are made of highest grade carbon steel from metal rolled in our own mills. This assures you of uniform quality. The fact that you can recognize and identify Neverslip by their corrugated surfaces is an added protection to you.

Our booklet, "Rattles - A Gripping Story," is full of practical, interesting information as to the many uses and special features of Neverslip Lock Washers. A copy will be sent you free on request. Lock Washer Division

National Umbrella Frame Company 30th and Thompson Sts., Philadelphia, $\mathrm{Pa}$

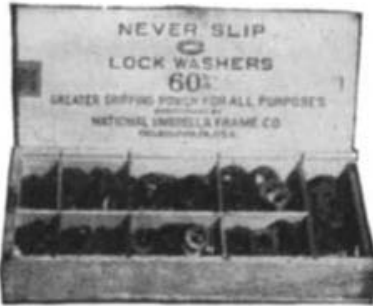

Hardware and Auto Supply Dealers can supply you with this special User's Assortment of 530 Neverslip Lock Washers of assorted sizes. 